\title{
Pemanfaatan Jaringan Wifi pada Pengendalian Lampu Rumah Berbasis Smartphone Android
}

\author{
${ }^{1}$ Muslimin, ${ }^{2}$ Arif Harjanto \\ Teknik Elektro FakultasTeknik Universitas Mulawarman \\ 1․ musculi@gmail.com, ${ }^{2}$ arif.harjanto@ft.unmul.ac.id
}

\begin{abstract}
Abstrak--Penelitian ini menghasilkan alat pengendali lampu dalam memberikan kenyamanan atau kemudahan menyalakan atau mematikan lampu di rumah. Metode yang digunakan dalam pembuatan kontrol pencahayaan berbasis mikrokontroler menggunakan smartphone android dan pemanfaatan jaringan wifi. Metode penelitian terdiri dari beberapa tahapan, penelitian kepustakaan, metode analisis, metode desain dan implementasi. Hasil yang dicapai adalah peningkatan aspek kenyamanan dan kemudahan dalam menghidupkan dan mematikan lampu. Jaringan wifi yang tersedia di smartphone android terhubung ke modul yang terhubung ke arduino mikrokontroler.
\end{abstract}

Kata kunci: Android, Mikrokontroler, Smartphone, Wifi

\section{Pendahuluan}

Perkembangan teknologi mendorong manusia untuk kreatif menciptakana penemuan baru. Memaksimalkan kinerja teknologi yang ada guna meringankan kerja manusia dalam kehidupan seperti pengendalian perangkat-perangkat elektronik yang digunakan dalam rumah tangga [1].

Lampu rumah merupakan salah satu penyumbang terbesar dalam pemakaian listrik. Penggunaan lampu yang kurang efisien menimbulkan pemborosan listrik yang mengakibatkan tagihan listrik membengkak. Kendali lampu rumah kebanyakan masih menggunakan saklar manual yang terpasang permanen pada masing-masing panel. Pemborosan listrik seringkali disebabkan karena lupa mematikan lampu. Apabila seluruh lampu dalam suatu rumah dikendalikan tanpa harus menyalakan saklar di dalam rumah maka peran mikrokontroler, smartphone android, serta fasilitas Wifi sangat penting untuk memberikan kenyamanan dan kemudahan dalam menghidupkan dan mematikan lampu [2].

Disisi lain perkembangan smartphone dengan system operasi android yang mendominasi pasar smartphone dunia semakin banyak tersedia di pasaran dengan harga yang semakin terjangkau [3]. Sistem operasi android sendiri bersifat sistem operasi yang open source yang dapat dimodifikasi sesuai kebutuhan. Sistem operasi open source yang ada pada ponsel pintar android memungkinkan untuk membuat aplikasi yang dihubungkan dengan rangkaian mikrokontroler dan relay untuk mengendalikan lampu rumah.

\section{DASAR TEORI DAN TINJAUAN PUSTAKA}

\section{A. Arduino Uno}

Uno Arduino adalah board berbasis mikrokontroler pada ATmega328 Board ini memiliki 14 digital input / output pin ( dimana 6 pin dapat digunakan sebagai output PWM), 6 input analog, $16 \mathrm{MHz}$ osilator kristal, koneksi USB, jack listrik tombol reset [1]. Pin-pin ini berisi semua yang diperlukan untuk mendukung mikrokontroler, hanya terhubung ke komputer dengan kabel USB atau sumber tegangan bisa didapat dari adaptor AC-DC atau baterai untuk menggunakannya.

Board Arduino Uno memiliki fitur-fitur baru sebagai berikut ( Gambar 1):

1,0 pinout: tambah SDA dan SCL pin yang dekat ke pin aref dan dua pin baru lainnya ditempatkan dekat ke pin RESET, dengan IO REF yang memungkinkan sebagai buffer untuk beradaptasi dengan tegangan yang disediakan dari board sistem. Pengembangannya, sistem akan lebih kompatibel dengan Prosesor yang menggunakan AVR, yang beroperasi dengan $5 \mathrm{~V}$ dan dengan Arduino Karena yang beroperasi dengan $3.3 \mathrm{~V} \mathrm{[4].}$

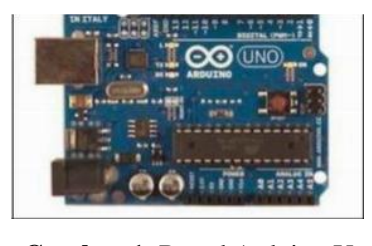

Gambar 1. Board Arduino Uno

\section{B. Modul Wifi}

Modul WiFi ini merupakan SoC (System on Chip) dengan stack protokol TCP/IP yang telah terintegrasi, sehingga memungkinkan mikrokontroler untuk meng-akses jaringan WiFi. Modul ini juga sangat mudah untuk dihubungkan dengan perangkat Arduino, atau dengan kata lain menjadi Arduino WiFi shield.

Modul ini juga mendukung APSD untuk aplikasi VoIP. Fiturfitur [1]: Menggunakan jaringan $802.11 \mathrm{~b} / \mathrm{g} / \mathrm{n}$., Wi-Fi Direct (P2P), soft-AP, Integrated TCP/IP protocol stack, Integrated TR switch, balun, LNA, power amplifier and matching network, Integrated PLLs, regulators, DCXO and power management units, $+19.5 \mathrm{dBm}$ output power in $802.11 \mathrm{~b}$ mode, Power down leakage current of $<10 \mathrm{uA}$, Integrated low power 32-bit CPU could be used as application processor, SDIO $1.1 /$ 2.0, SPI, UART, STBC, $1 \times 1$ MIMO, 2×1 MIMO, A-MPDU \& A-MSDU aggregation \& $0.4 \mathrm{~ms}$ guard interval (Gambar 2). 


\section{METODE PENELITIAN}

Penelitian ini menggunakan beberapa metode yang digunakan sebagai panduan dalam perancangan. Antara lain menggunakan metode analisis, metode desain dan implementasi.

\section{A. Analisis Kebutuhan Hardware}

Kebutuhan Hardware utama yang digunakan dalam mengimplementasikan pemanfaatan jaringan Wifi untuk pengendalian lampu rumah adalah sebagai berikut :

1. Mikrokontroller ATMega 328 (Arduino Uno), sebagai otak dari sistem elektronika yang memberi perintah pada komponen-komponen lain.

2. Modul Wifi ESP8266, sebagai sarana komunikasi Antara mikrokontroller dengan jaringan internet atau Ethernet tanpa memerlukan bantuan komputer.

3. Modul Relay 4 Channel Relay adalah komponen yang dapat digunakan sebagai saklar elektronik. Secara singkat, cara kerja relay adalah memanfaatkan magnet buatan untuk memicu kontaktor dari keadaan off menjadi on, atau sebaliknya.

4. Lampu LED (Light Emitting Diode) adalah komponen elektronika yang dapat memancarkan cahaya monokromatik ketika diberi tegangan maju.

5. Komputer (Laptop) dengan Wifi, Wifi disini sebagai penerima sinyal yang dipancarkan oleh ESP8266 dan komputer untuk menampilkan program.

6. Power Supply, berfungsi untuk memberi pasokan energi listrik ke hardware baik Mikrokontroller maupun Modul Wifi. Power supply yang dipakai adalah bertegangan 12 Volt.

\section{B. Perancangan Hardware}

Perancangan perangkat keras merupakan rancangan atau rangkaian dari alat yang digunakan untuk membangun prototipe pengendalian lampu rumah berbasis mikrokontroler arduino menggunakan smartphone android.

Rangkaian relay module dengan arduino digunakan untuk menghubungkan atau memutuskan arus listrik kepada lampu yang terhubung. Rangkaian ini dirancang sesuai program mikrokontroler arduino, dimana terdapat sinyal kontrol dari mikrokontroler arduino dapat dilihat pada Gambar 3.

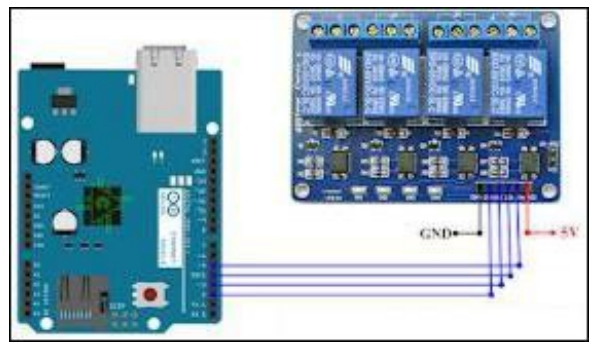

Gambar 3. Perancangan Relay Modul dan Arduino

Rangkaian Wifi module ESP8266 dengan arduino digunakan untuk menghubungkan antara smartphone android dengan wifi module yang terhubung dengan board Arduino agar perintah-perintah yang dikirim dari smartphone android dapat diterima dan dieksekusi oleh mikrokontroler Arduino melalui komunikasi jaringan wifi. Perancangan seperti pada Gambar 4.

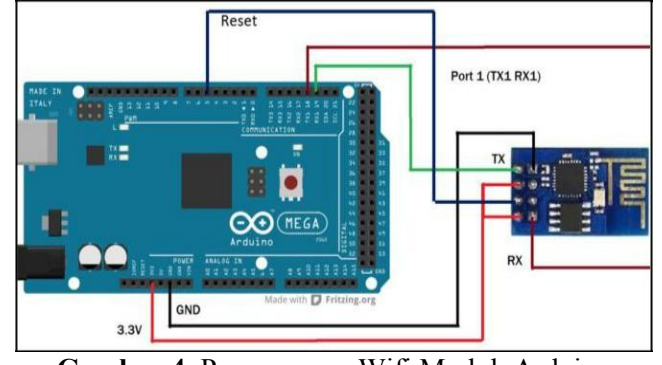

Gambar 4. Perancangan Wifi Modul Arduino

\section{Perancangan Software}

Perancangan Software dapatdibedakan menjadi dua bagian yaitu perancangan software pada modul pengendali utama (Papan Mikrokontroler Arduino Uno) dan perancangan software pengendali pada smartphone android sebagai antarmuka untuk pengguna.

Berikut flowchart proses upload kode program atau sketch ke papan Arduino:

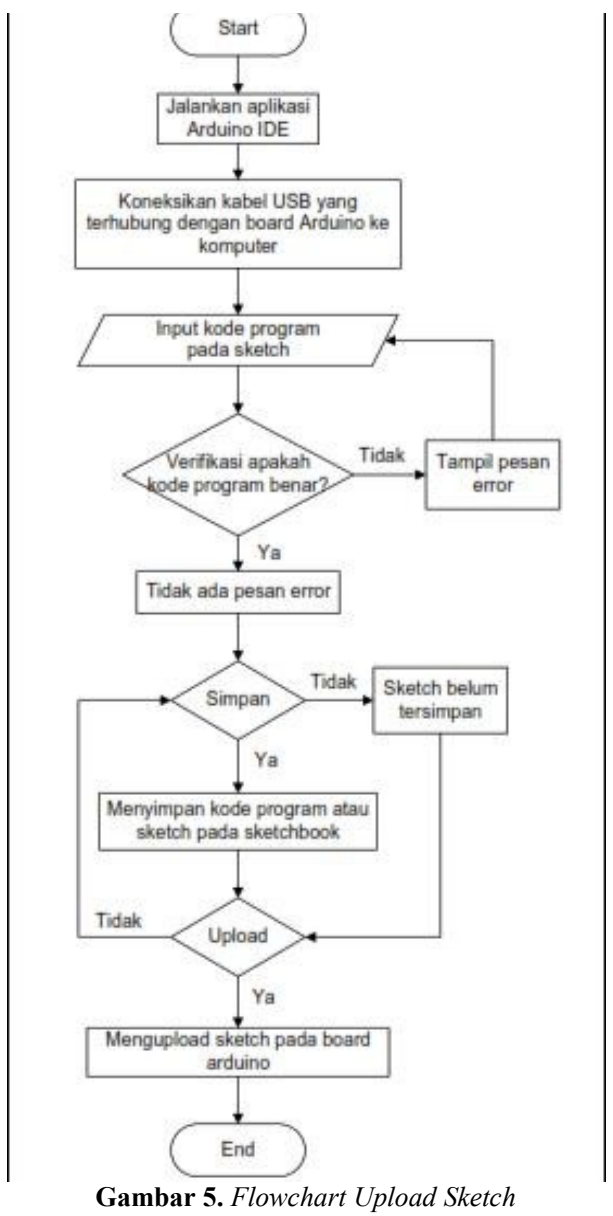

Langkah awal yang harus dilakukan adalah dengan menentukan logika yang akan diterapkan pada lampu yang akan dikendalikan, kemudian membuat algoritmanya yang kemudian di implementasikan menggunakan Arduino IDE. Berdasarkan tabel 1 logika lampu, maka dibuatlah flowchart input perintah ke papan Arduino seperti pada Gambar 6 di bawah ini. 
Tabel 1. Logika Lampu

\begin{tabular}{|c|c|c|c|c|}
\hline Perintah & $\begin{array}{c}\text { Ruang 1 } \\
\text { (4 lampu) }\end{array}$ & $\begin{array}{c}\text { Ruang 2 } \\
\text { (4 lampu) }\end{array}$ & $\begin{array}{c}\text { Ruang 3 } \\
\text { (4 lampu) }\end{array}$ & $\begin{array}{c}\text { Teras } \\
\text { (2 lampu) }\end{array}$ \\
\hline 1 & ON /OFF & - & - & - \\
\hline 2 & - & ON / OFF & - & - \\
\hline 3 & - & - & ON / OFF & - \\
\hline 4 & - & - & - & ON / OFF \\
\hline
\end{tabular}

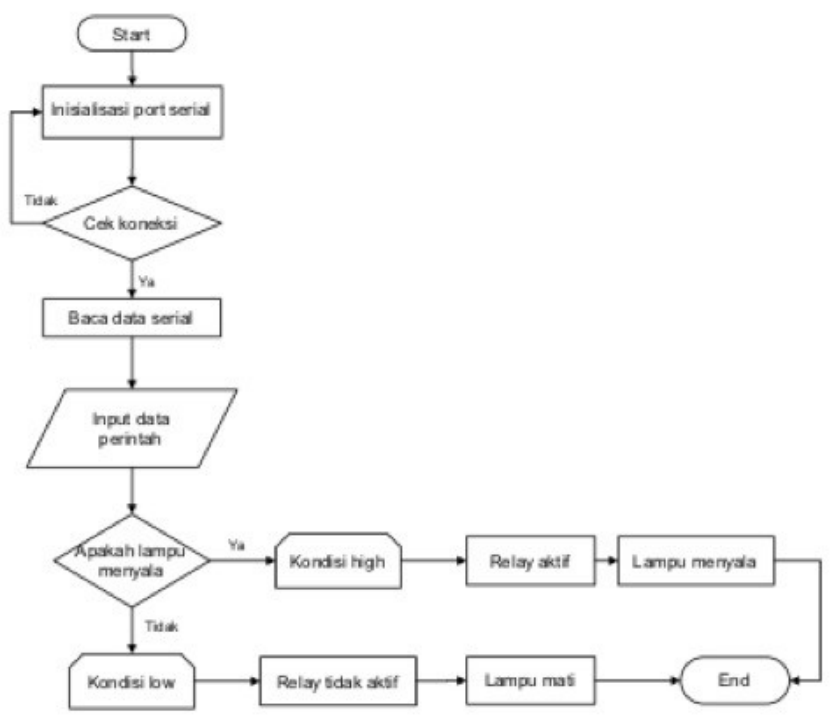

Gambar 6. Flowchart Input Arduino

Perancangan aplikasi pada smartphone android dalam sistem ini merupakan tampak tampilan awal dariprogram yang tampil pada layar smartphone android yang bertujuan untuk memberikan gambaran tentang aplikasi yang akan dibuat, Berikut ini adalah rancangan tampilan awal pada aplikasi android yang akan digunakan untuk mengendalikan lampu. Dapat dilihat pada Gambar 7.

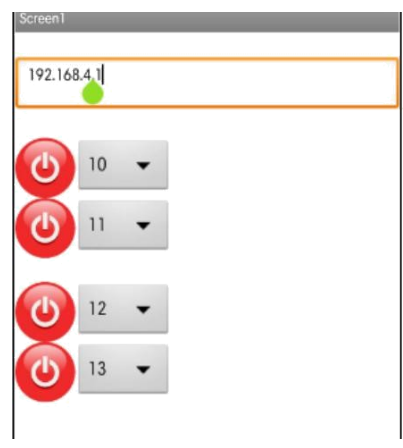

Gambar 7. Tampilan Aplikasi Pengendali Pada Smartphone Android

\section{HASIL DAN PEMBAHASAN}

Penggunaan jaringan Wifi pada pengendalian lampu rumah berbasis Android ini berfungsi untuk menyalakan dan mematikan lampu rumah tanpa menggunakan saklar. Pada sistem ini dikendalikan menggunakan Mikrokontroler ATMega328. Penghubung antara Mikrokontroler ATMega328 dengan aplikasi pada smartphone android menggunakan Modul Wifi ESP8266. Aplikasi yang digunakan untuk menghubungkan ke jaringan Wifi pada smartphone Android pada sistem ini dibuat dengan websiteMIT App Inventor. Website MIT App Inventor ini berfungsi untuk membuat aplikasi pendukung agar smartphone Android yang digunakan dapat menghidupkan dan mematikan lampu rumah menggunakan jaringan Wifi.

\section{A. Implementasi Hardware}

Mikrokontroler ATMega328 merupakan otak dari sistem yang dibuat. Mikrokontroler ini berfungsi sebagai pengatur kerja pada sistem. Di Mikrokontroler ini sudah diprogram sesuai dengan perintah-perintah yang akan dijalankan. Gambar 8 merupakan rangkaian Mikrokontroler ATMega328 yang dipakai.

LED merupakan komponen elektronika yang dapat memancarkan cahaya ketika diberikan tegangan. LED digunakan pada perancangan sistem pengendalian lampu rumah berbasis Android ini untuk menggantikan bola lampu yang semestinya digunakan. Gambar 9 merupakan gambar dari LED yang digunakan.

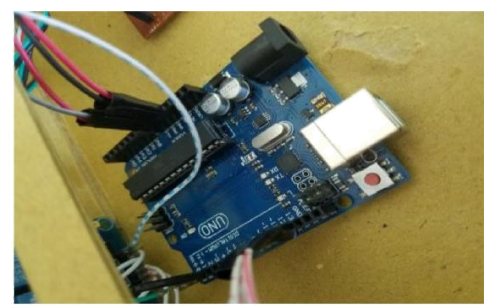

Gambar 8. Mikrokontroler ATMega328

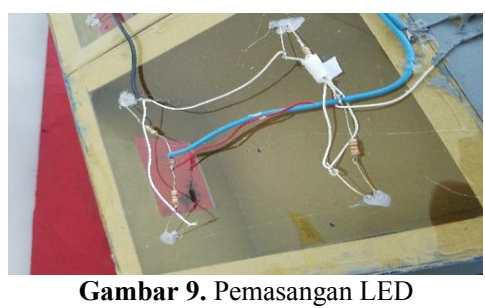

Perangkat yang memasok energi listrik untuk satu atau lebih beban listrik. Pada sistem ini power supply digunakan untuk memberi pasokan energi listrik ke hardware baik Mikrokontroler maupun Modul Wifi ESP8266. Power supply yang dipakai adalah bertegangan 12 Volt. Gambar 10 merupakan gambar power supply yang digunakan pada sistem ini.

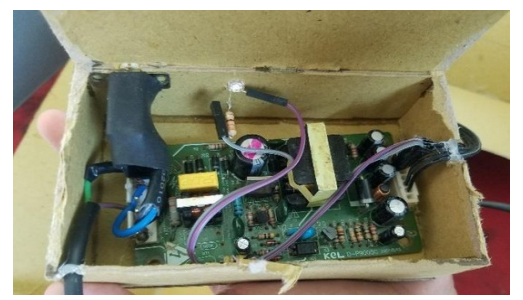

Gambar 10. Power Supply

\section{B. Gambaran Alat Pengendalian Lampu}

Mempermudah penggunaan program yang telah dibuat, maka akan dijelaskan cara penggunaanya. Hal ini bertujuan 
untuk menjelaskan bagi user khususnya pemilik rumah di rumah dalam mengoperasikan program tersebut dan mempermudah penggunaan program. Tetapi sebelum menggunakan program pastikan bahwa hardware telah diaktifkan dan smartphone Android telah dikoneksikan ke jaringan Wifi. Untuk menggunakan aplikasi di smartphone Android ini pengguna harus memasukkan IP Wifi dari modul Wifi ESP8266, lalu pengguna harus mengkonfigurasikan pin apa saja yang terhubung dengan lampu. Selanjutnya, untuk menghidupkan dan mematikan lampu pengguna dapat menekan tombol ON/OFF pada aplikasi di smartphone Android.

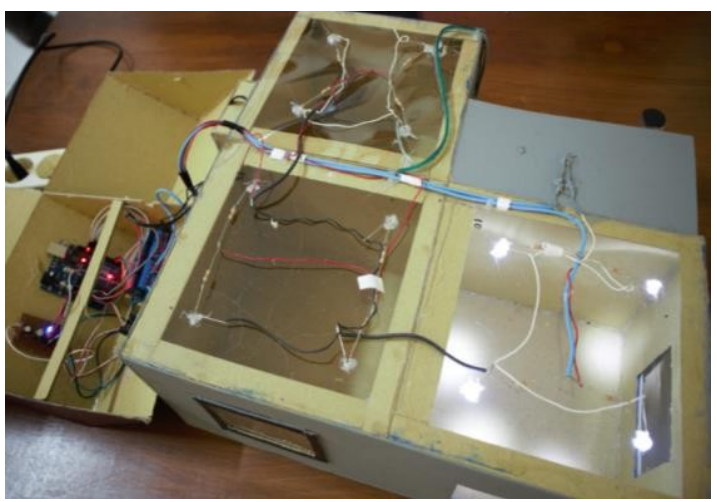

Gambar 11. Pengendalian Lampu Rumah

Tabel 2. Hasil Pengujian Pengendali LED dengan Aplikasi pada Smartphone Android

\begin{tabular}{|c|c|c|c|c|}
\hline No & $\begin{array}{c}\text { Konfigursi } \\
\text { pin }\end{array}$ & $\begin{array}{c}\text { Status } \\
\text { LED }\end{array}$ & Pengamatan & Kesimpulan \\
\hline 1 & 10 & Ruang 1 Menyala & Ruang 1 mati & Diterima \\
\cline { 3 - 5 } & \multirow{2}{*}{2} & Ruang 1 Mati & Ruang 1 Menyala & Diterima \\
\hline \multirow{2}{*}{3} & 11 & Teras Menyala & Teras mati & Diterima \\
\cline { 3 - 5 } & \multirow{2}{*}{12} & Ruang 2 Menyala & Ruang 2 Mati & Diterima \\
\cline { 3 - 5 } & & Ruang 2 Mati & Ruang 2 Menyala & Diterima \\
\hline 4 & 13 & Ruang 3 Menyala & Ruang 3 Mati & Diterima \\
\cline { 3 - 5 } & & Ruang 3 Mati & Ruang 3 Menyala & Diterima \\
\hline
\end{tabular}

Tabel 3. Hasil Pengujian Jangkauan Wifi

\begin{tabular}{|c|c|c|}
\hline Jangkauan & Kondisi & Kesimpulan \\
\hline $1-5$ Meter & $\begin{array}{l}\text { Ruangan Terbuka } \\
\text { Ruangan Tertutup }\end{array}$ & Sinyal Diterima \\
& $\begin{array}{l}\text { Ruangan Terbuka } \\
\text { Ruangan Tertutup }\end{array}$ & Sinyal Diterima \\
\hline $6-10$ Meter & $\begin{array}{l}\text { Ruangan Terbuka } \\
\text { Ruangan Tertutup }\end{array}$ & Sinyal Diterima \\
\hline $11-15$ Meter & $\begin{array}{l}\text { Ruangan Terbuka } \\
\text { Ruangan Tertutup }\end{array}$ & - \\
\hline 16 Meter & $\begin{array}{l}\text { Ruangan Terbuka } \\
\text { Ruangan Tertutup }\end{array}$ & Sinyal Hilang \\
\hline 19 Meter & & \\
& & \\
\hline
\end{tabular}

\section{KESIMPULAN}

1. Perancangan sistem kendali relay lampu menggunakan smartphone android dengan memanfaatkan fasilitas Wifi, hal ini dapat memudahkan pengguna untuk mengendalikan lampu rumah tanpa menghidupkan atau mematikan saklar lampu secara manual, hanya dengan menekan tombol yang ada pada aplikasi smartphone Android maka pengguna sudah dapat mengendalikan lampu dengan memanfaatkan fasilitas Wifi. Pengguna juga dapat memantau lampu apa saja yang telah menyala maupun lampu yang telah mati dengan menggunakan aplikasi yang telah dibuat pada smartphone android.

2. Dengan merancang prototype ini waktu yang dibutuhkan untuk menyalakan atau mematikan lampu dapat menjadi lebih efisien. Hal ini tentunya akan memberikan kenyaman dan kemudahan bagi pengguna smartphone Android.

\section{DAFTAR PUSTAKA}

[1] Hantoro, Gunadi Dwi. 2010. Wifi (Wireless LAN) Jaringan Komputer Tampa Kabel.Yogyakarta : Andi Offest.

[2] Irawan. 2012 Membuat Aplikasi Android Untuk Orang Awam. Palembang: Maxikom.

[3] Sumardi. 2013. Mikrokontroler Belajar AVR Mulai Dari Nol. Yogyakarta: Graha Ilmu.

[4] Supardi, Yuniar 2012 Sistem Operasi Andal Android. Jakarta: PT Elex Media Komputindo.

[5] Wibowo, Arief. 2011. Mikrokontroler Atmega8535 Learning Media.Jakarta : PT. Elex Media Komputindo. 